\title{
27. Key developments and future prospects in the study of transnational families
}

\author{
Laura Merla, Majella Kilkey, Raelene Wilding, and Loretta \\ Baldassar
}

\section{FROM 'MIGRANT' TO 'TRANSNATIONAL' FAMILIES}

Today, the terminology of transnational families is common in research, and increasingly appears in public and political debates as well (e.g., COFACE 2012). This term is, however, relatively new, and its use both reflects and supports a wider shift in migration studies that began at the turn of the Millennium and that has been called the 'transnational turn'. During the mid-1990s, and based on the observation that family members regularly engage in transnational practices across national borders, anthropologists Linda Basch, Nina Glick-Schiller, and Cristina Szanton-Blanc proposed a reconceptualisation of the dominant representation of migrants as 'uprooted' from their country of origin; rather, they advocated conceiving of migrants as 'transmigrants' who maintain multiple links and connections with their home societies (Basch et al. 1994; Glick Schiller et al. 1992; Schiller et al. 1995). Their approach was widely endorsed by migration scholars, and inspired a wave of social and political science research highlighting the importance of economic, cultural, political, religious, and social transnational dynamics (Vertovec 2009) and transnational social fields that connect sending and receiving societies (Levitt and Glick Schiller 2007; Levitt and Jaworsky 2007). Transnationalism in this context is defined as 'a social process in which migrants establish social fields that cross geographic, cultural, and political borders' (Glick Schiller et al. 1992, p. ix). Thus, migration is no longer conceived of as a one-way movement from one country to another, and national belonging is no longer seen as an either-or scenario. This conceptualisation has been further fuelled by the development and democratisation of transportation and communication technologies. These technologies have (under certain conditions) facilitated mobility and connectedness, which can be seen as another transformation that has simultaneously led to what has been coined the 'mobility turn' in social sciences (Sheller and Urry 2006; Urry 2000, 2007).

Although, as Vertovec (2009, p. 61) noted, '[t]he provenance of most everyday migrant transnationalism is within families', familial transnational practices had been largely neglected in mainstream transnationalism scholarship, which considered them as 'weak' forms of transnational engagement, as opposed to the 'stronger' forms that take place in the 'public' sphere (Gardner and Grillo 2002; Legall 2005). In this context, feminist scholarship has played a key role in illuminating the issue of female migration, and in bringing the topic of family migration onto the centre stage (Parreñas 2000). This scholarship challenged the then common bias in migration studies that characterised men as drivers of migration and women as followers. These studies showed that large numbers of women from the Global South migrate alone to the Global North in pursuit of better economic prospects, and highlighted how the absence of mothers can pose challenges for their non-migrant children and wider communities. The term 
'transnational motherhood' was coined by Pierrette Hondagneu-Sotelo and Ernestine Avila (1997) to capture the alternative constructions of motherhood actively created by Central and Latin American women leaving their children 'back home' in order to work in the United States as nannies or housekeepers. Subsequent studies of transnational motherhood continued to focus primarily on female migrant domestic workers in the Global North, locating them in a broader economic and political context of exploitation; i.e., in an international division of reproductive labour (Parreñas 2000) also known as 'global care chains' (Ehrenreich and Hochschild 2003; Hochschild 2000).

While the theoretical foundations of transnational motherhood studies emerged in America, the term 'transnational families' first appeared in European scholarship. In 2002, Bryceson and Vuorela published their edited book, The Transnational Family: New European Frontiers and Global Networks. The volume presented the results of a conference on migrant families in Europe held at the African Studies Centre in Leiden in 1999, which brought together social scientists whose work documented 'the creativity of people in devising ways and means of sustaining the idea of familyhood amidst family members' worldwide dispersal' (Bryceson and Vuorela 2002b, p. xi). The editors defined transnational families as 'families that live some or most of the time separated from each other, yet hold together and create something that can be seen as a feeling of collective welfare and unity, namely familyhood, even across national borders' (Bryceson and Vuorela 2002a, p. 18). This definition is now the most commonly used in the field.

As Legall (2005) has noted, scholarship on transnationalism and families can be divided into two (not mutually exclusive) strands: transnational parenting (with mothering centre stage); and transnational kinship (mainly referred to as transnational families literature), which embraces a wider definition of the family, including inter- and intra-generational relationships beyond nuclear families (Baldassar et al. 2014; Crespi et al. 2018; Mazzucato 2013). Although the themes covered by the latter strand are wide ranging, a special emphasis has been placed on the key role care plays in the maintenance of family relationships across distance and national borders (e.g., Baldassar et al. 2007; Barglowski et al. 2015; Fog Olwig 2014; Huang et al. 2012; Leifsen and Tymczuk 2012; Merla 2015; Radziwinowiczówna et al. 2018; Reynolds and Zontini 2006).

Care has been a central theme in our own work on transnational families. The concept of 'transnational care' was first introduced by Baldassar et al. (2007) in their analysis of the ways adult migrant children in Perth, Western Australia - one of the most geographically isolated capital cities in the world - manage to care for their ageing parents across vast distances, including in Europe (Italy, Ireland, and the Netherlands). Their conceptualisation of transnational caregiving as a set of practices governed by a dialectic of capacity, cultural obligation, and negotiated family commitments drew on Finch and Mason's (1993) analysis of the negotiation of family obligations to provide (proximate) care and support, and their broad definition of care as involving physical, financial, emotional, and practical support, as well as accommodation. This work was extended by Baldassar and Merla, who identified a set of resources (or capabilities) supporting transnational family members' capacity to provide - and receive - care, including mobility, communication, social relations, time, money, knowledge, and appropriate housing (Merla 2012; Merla and Baldassar 2011). In 2014, they proposed a new conceptualisation of care flows as care circulation (Baldassar and Merla 2014), in part in response to the focus in Global Care Chains on care dyads; and in order to emphasise the extended, intergenerational, and complex care relationships that characterise transnational 
families. Care circulation is thus defined as 'the reciprocal, multidirectional and asymmetrical exchange of care that fluctuates over the life course within transnational family networks subject to the political, economic, cultural and social contexts of both sending and receiving societies' (Baldassar and Merla 2014, p. 22). This framework also helped to illuminate largely invisible actors of care flows, including men (Fresnoza-Flot 2014; Kilkey 2014) and children (Fog Olwig 2014; Poeze and Mazzucato 2014).

\section{TRANSNATIONAL FAMILIES AND (SOCIAL) POLICIES}

While it was initially informed predominantly by anthropological and sociological perspectives, in more recent years a social policy lens has been applied to transnational family scholarship. This approach emphasises the institutional contexts that help shape the circulation of care among families across borders. Above all, this literature highlights the role migration policies can play in creating transnational families by restricting the rights of family members to accompany migrants, or to subsequently reunite with family members who have migrated. In the European context, two main types of transnational families have been prominent in this research. The first is that of migrant care workers from Third Countries ${ }^{1}$ who, because of either their irregular migration status or the conditions imposed by their entry and residence visas, are forced to leave family members behind in the country of origin, including spouses, children, and older dependents (Lutz and Palenga-Möllenbeck 2012). The second type refers to migrants arriving in Europe as part of the so-called 'refugee crisis' in 2015-16 (see Kushnir et al. 2020). As a result of a tightening of asylum and refugee policies, regulations, and practices in the countries of destination - as well as restrictive practices on route through the Middle East and Europe, such as detention - those recent arrivals now have family members scattered within and across continents (Näre 2020).

A social policy lens has also been applied to draw attention to the institutional 'gaps' that create the need for ongoing family solidarities across borders. Studies have highlighted the weak or non-existent welfare provision in the migrants' countries of origin in the Global South and the poorer regions of Europe, which reinforce the critical role played by remittances in sustaining the well-being of family members back home (Yeates and Owusu-Sekyere 2019). These studies illuminated institutional weaknesses in the countries of destination. For example, when migrants lack access to child care, or if the care is unaffordable or of poor quality, grandparents from abroad may be mobilised to provide care for their grandchildren while their migrant parents work (Kilkey et al. 2013; Nedelcu and Wyss 2020; Ryan 2011; Wilding and Baldassar 2009). Institutional gaps in the countries of origin and of destination have been exacerbated in the context of global neoliberal governance, which has been shaping societies according to market principles since the 1980s. The emphasis on individual responsibility has further intensified since austerity measures were introduced following the global financial crisis of 2008-2009 (Baldassar et al. 2018). Such processes are producing what has been called a 'crisis of care' (Baldassar 2016a) or a 'crisis of social reproduction' (Kofman and Raghuram 2015), which has reinforced the need for transnational family welfare safety nets (Baldassar et al. 2018).

In addition to describing the emergence of transnational families and the growing need for family solidarity across borders, social policy analysts have shown how institutional contexts are shaping the capacity of family members to meet those needs. This dynamic is captured 
most comprehensively in Kilkey and Merla's (2014) notion of 'situated transnationalism'. Informed by Baldassar and Merla's (2011) work on the resources required for transnational caregiving (see above), situated transnationalism identifies the social and public policy realms through which those resources are partially derived in countries of origin and of destination, and in global/international sites of governance. Informed further by welfare state theory (Esping-Andersen 1990), situated transnationalism focuses on the relevant arrangements in migration, welfare, and gendered care and working-time regimes. It also highlights the importance of policies that affect the availability and affordability of cross-border transport, and of policies that influence the quality and accessibility of telecommunications infrastructure, including information and communication technologies (ICT).

Kilkey and Merla (2014) emphasised that the various regimes and regulations intersect to create contexts that facilitate or hinder the circulation of care within different types of transnational families and across all social categories, albeit in highly differentiated ways. Migrant care workers are, however, often treated as the paradigmatic case in research on the degree to which migrants' transnational care responsibilities are recognised in European societies. The presence of large numbers of migrant care workers in Europe is in large part the result of European states adopting transnational solutions to their own 'care crises', which have emerged in the context of demographic ageing, increasing employment among women, and neoliberalism (Kilkey et al. 2018). However, European states' transnational practices in the area of care are deeply asymmetrical. Focusing on migrants from the Global South, Degavre and Merla (2016) showed that migrant women are often excluded from accessing European societies' care systems to support their own transnational family care needs The reasons are two-fold. First, the workers' precarious positioning on the secondary labour market as migrants - many of whom are on temporary and circular visas - doing low-skilled work largely disqualifies them from accessing many state supports. Second, the welfare and care provisions of states operate according to the principle of 'territoriality' (Böcker and Hunter 2017), which implies 'first that welfare state benefits are preserved for persons residing or working on the state territory, and secondly that they must be consumed on the state territory' (2017, p. 355). Thus, while states may operate transnationally to solve their care crises, the transnational care responsibilities of migrant care workers are largely unrecognised, generating inequalities between migrants and non-migrants, and especially among the women who are most engaged in transnational care giving (Williams 2018).

Degavre and Merla's (2016) argument was developed in relation to migrants from the Global South. They acknowledged that for mobile European Union (EU) citizens, including those engaged in care work, who migrate under European Free Movement provisions, several measures in particular tend to facilitate the transnational circulation of family care. These include the portability of pensions, which allows European retirees who move to another member state to look after their grandchildren to receive their pension benefits abroad; parental leave benefits, which enable workers to take time off to care for a child while residing in another EU country; and cash benefits to support children 'left behind' in another EU country. Therefore, as Kilkey and Urzi (2017) have argued, we also need to be attuned to the patterns of 'stratified social reproduction' based on migrant status that are embedded in European societies. While the differences in the rights accorded to mobile EU citizens and Third Country nationals represent a key axis of stratification in Europe in the capacity of families to socially reproduce themselves in the process of migration, we should note that the relatively privileged position of EU migrants vis-à-vis welfare systems is increasingly contested in a number of 
member states, with the United Kingdom in the context of Brexit being the most prominent example (Kilkey 2017).

Näre (2013) has cautioned against assuming that non-migrant women in Europe and their family members are clear 'winners' in their government's transnational approach to solving the care crisis. Applying an intersectional lens, she argued that European women who employ migrant care workers, particularly in the familial welfare regimes of southern Europe, are themselves often unemployed or underemployed, and carry significant care burdens of their own that make hiring migrant care workers their only affordable solution. Näre (2013) highlighted the ethical challenges inherent in this scenario, not only from the perspective of the migrant care workers, but from that of the families who use their services.

In a departure from social policy analysts' dominant focus on formal/public welfare provision, recent work in the area of transnational social protection has emphasised 'social protection constellations', which incorporate 'not only nation-states, but also migrants themselves, NGOs [non-governmental organisations], religious communities, and international organizations' (Faist 2017, p. 21). As Faist has pointed out, migrants negotiate between these more informal welfare systems and formal welfare schemes, from which, as we noted above, they are often fully or partially excluded. Faist's (2017) focus was on how formal and informal systems of social protection intersect to (re)produce transnational inequalities between places. However, through the concept of 'care and protection assemblage(s)', Amelina (2017) has extended this research on the formal and the informal systems in the realm of social protection to examine the resulting inequalities between families in their ability to provide care in the process of migration. In a further departure from the dominant focus of the abovementioned literature, Amelina and Bause (2020) most recently applied the concept of 'care and protection assemblage(s)' to the situation of forced migrants in Europe who arrived during the so-called 'refugee crisis' in 2015-16 (Kushnir et al. 2020). Amelina and Bause (2020) analysed how informal, semiformal, and formal care and protection arrangements interact to secure the welfare of transnational families within such contexts, and emphasised the production and reproduction of inequalities in the capacity to access such arrangements, particularly in terms of gender and legal status.

\section{TRANSNATIONAL FAMILIES AND COMMUNICATION TECHNOLOGIES}

In addition to studying the regimes, regulations, and policies that shape transnational families, migration scholars are increasingly recognising the importance of the material contexts within which transnational families are sustained. In particular, the rapid changes in ICT are transforming how families communicate, how they imagine themselves, and how they organise their everyday lives. The scale of this transformation is made clear if we consider two key books in the field. In Bryceson and Vuorela's (2002) edited book, The Transnational Family, the communication tools used to maintain and connect transnational families were only mentioned a handful of times. When they were mentioned, it was to indicate that international telephone calls are prohibitively expensive, or to suggest that family histories of letter writing were gradually being replaced by email communications. This is in stark contrast to the account of transnational family life published only 10 years later by Madianou and Miller (2012, p. 3), which demonstrated that transnational families have become embedded in 'poly- 
media environments', in which the affordability of a particular communication option has been displaced by other concerns: i.e., by the 'social and moral questions rather than technical or economic parameters' of the multiple modes of communication that are readily available.

In interviews conducted with Irish migrants at the turn of the century, Wilding (2006) noted that histories of communication are also histories of family relationships, and of a sense of familyhood. Prior to the 1990s, families had relied primarily on letters to communicate with each other. This mode of communication was slow, with letters often taking weeks or even months to travel between Europe and Australia. However, when composed by a skilled writer, these letters were rich in detail, and created a unique form of intimacy between the writer and the reader. International telephone calls, while possible, were prohibitively expensive at the time, and had a very different emotional impact. This was largely because they were typically used to convey urgent information, such as an illness or a death in the family. In contrast to the pleasures of a letter, an unexpected phone call was something to be feared, not enjoyed.

By the 1990s, transnational families were increasingly able to rely on emails, faxes, cheaper telephone calls, and remittance technologies (Baldassar et al. 2007; Madianou and Miller 2011; Panagakos and Horst 2006; Yujuico 2009). These tools intensified the frequency of contact, while also changing the content and the direction of communications. For example, while letters were often exchanged between mothers and daughters, emails were more likely to bring brothers, sisters, cousins, and other family members into more complex multi-directional communication patterns (Wilding 2006). However, none of these technologies were as transformative as the introduction of the mobile phone. Unlike the fixed line telephone, which belongs to a household or a community, the mobile telephone is 'mobile; flexible and customisable; associated with a person rather than a household' (Goggin 2006, p. 2). This technology has enabled some of the poorest people in some of the world's poorest nations, such as the Philippines, to leap forward in their telecommunication capacities, and to engage economically, socially, and culturally across the globe, without having to bear the burden of installing or maintaining expensive landline infrastructure (Portus 2016).

One of the most significant contributions of the mobile phone to contemporary social life was conceptualised by Christian Licoppe (2004). Although he focused on proximate family relationships, and did not explicitly address the transnational family, he highlighted the emergence of 'connected relationships', in which 'the (physically) absent party renders himself or herself present by multiplying mediated communication gestures up to the point where copresent interactions and mediated communication seem woven in a seamless web' (Licoppe 2004, p. 135). It is this capacity of members of transnational families to seemingly defy distance by making themselves 'present' in each other's lives through ICT that has been the focus of recent transnational family research.

There is now ample evidence that the practices of transnational connection and care have changed and expanded over time as the technologies available to support them have diversified. These significant transformations have raised questions about whether these polymedia environments are creating new ways of caring, thereby challenging our normative ideas about how we care, and, in particular, the importance of physical proximity to family and caring relationships (Baldassar et al. 2016). Building on previous work that identified communication and visiting practices as fundamental to transnational family care (Baldassar et al. 2007), Baldassar (2008) argues that these can be categorised into four types of co-presence: virtual (created through various ICT), imagined (created through thoughts and prayer), physical 
(created in proximate face-to-face settings), and proxy (created indirectly through objects and people whose physical presence embodies the spirit of the absent person).

These technological transformations also have implications for how transnational families maintain relationships and perceive their relationships. For example, Madianou and Miller (2012) demonstrated that the mobile phone has changed what it means to be a mother who travels overseas for work. The women they interview work overseas to provide their children with higher levels of education and material comfort. In the past, fulfilling this goal required mothers to relinquish their involvement in the lives of their children, with some left-behind children no longer recognising their despairing mothers. Access to mobile phones and social media now means that mothers can remain in constant contact with their left-behind children, including monitoring their friendships and school attendance, assisting them with their homework, and participating in family meals. The resulting relationships are not necessarily positive or idyllic. Some children resist what they see as surveillance and micromanagement from their mothers, and some mothers report that the level of intimacy with their children is still unsatisfactory (Madianou and Miller 2012; Parreñas 2005). However, compared with the experiences of earlier generations, these long-distance parenting relationships more closely approximate the complex and multi-layered relationships that mothers and children navigate when living in the same household.

It is not just mothers who engage in transnational parenting across distance. Indeed, the combination of newly emerging models of 'involved' fathering and new communication technologies seem to be contributing to shifting practices of 'transnational fathering'. Early transnational families research has suggested that while both mothers and fathers are expected to provide financial and material support from a distance, only mothers are responsible for providing emotional care (e.g., Hondagneu-Sotelo and Avila 1997; Parreñas 2005). However, there is evidence that this gender division is shifting. For example, research with Polish male migrants living in the United Kingdom has demonstrated that fathers, like mothers, are increasingly being called upon to perform the emotional labour of long-distance relationships that was once primarily the responsibility of women (Holmes 2014; Kilkey et al. 2013; Lee 2019).

What is clear from this body of research is that communication technologies are particularly important to families who have a limited ability to share physical co-presence. This point is especially evident in research on asylum seekers and irregular migrants (e.g., Harney 2013). For example, Alexandra Greene's (2019) recent work with refugee women in Greece showed how phones provide these women with opportunities to maintain connectedness with family, and to resist the potential despair that can arise while waiting to secure a safe, permanent home. The dispersal of family networks as a result of forced migration has inspired innovative uses of digital media to reproduce a sense of familyhood and connectedness. For example, Robertson et al. (2016) observed in their research on young Burmese refugees that these young people have experienced two forms of separation from family: first when fleeing violence in Burma, and then again when being resettled in countries around the world. One of the creative responses of these young people to this separation has been to use digital media to manipulate images of themselves and their family members in order to reposition them in the same space. In this way, they create a 'family imaginary' that denies the separation that has been imposed on them by persecution and migration regulations.

Imaginaries of family and belonging can also be extended to whole communities, particularly in cases in which the migrants' homeland has been destroyed. Hariz Halilovic (2013) 
has written evocatively about how migrants of the Bosnian diaspora have, in the absence of a shared physical home, come to rely on virtual spaces to create community and family ties. In addition, there is evidence that having access to virtual communities is of particular importance to marginalised people, such as live-in care workers who often have little free time and limited mobility beyond the confines of their employer's home (Brown 2016). These are stark examples of relationships that would not exist without access to new technologies - and yet, arguably, all transnational relationships are to varying degrees co-constituted by the technologies themselves, i.e., the devices themselves give substance to relationships (Ahlin 2018). Similarly, Baldassar (2016b) has hypothesised that communication technologies are an example of what Bennett has called 'vibrant matter', because they have 'the capacity ... not only to impede or block the will and designs of humans but also to act as quasi agents or forces with trajectories, propensities, or tendencies of their own' (Bennett 2010, p. viii).

More recently, Baldassar and Wilding (2020) have proposed the notion of digital kinning - defined as the inherently relational practices and processes of caring through the use of new technologies - to highlight the role of these technologies in the care networks of older people. The term kinning emphasises that these new technologies are embedded in social relationships of reciprocity based on the exchange of care and support. Given their relational nature, all of these digital practices involve forms of relationship building, maintenance, or curation, which are well captured by the concept of kinning. In the case of older people's care networks, these digital kinning practices often require facilitation by others, which tends to reinforce their social relational nature. It is in these creative and diverse practices at the intersection of materialities, mobilities, and technologies that we see how technologies are transforming families and relationships.

\section{CONCLUSION AND FUTURE DIRECTIONS FOR RESEARCH}

To date, research on transnational families and care circulation (including our own) has been largely focused on 'de-demonising' distance and highlighting the important role of the reciprocal exchange of care across national borders using ICT and new technologies. Some of this work has, however, inadvertently underemphasised the important role of physical proximity, and the related mobility rights required to support it, in the practices and processes of transnational care circulation trajectories. The current political context of austerity that arose in response to the 2008 Global Financial Crisis (ILO 2014; Ortiz et al. 2015) and restrictionist migration policies are dramatically affecting transnational families, both by reinforcing their importance as safety networks and welfare providers, and by affecting their capacity to play these roles both locally and transnationally (Baldassar et al. 2018). Transnational linkages sustained by the circulation of bodies, which have been made possible through increasingly affordable and available modes of travel, have been placed under severe strain by today's policies and rhetorical statements of 'closure, entrapment and containment' (Shamir 2005, p. 199). A growing body of literature is currently exploring the intersections between mobility regimes and family relations (Bonizzoni 2018; Kilkey 2017; Kofman and Raghuram 2015; Van Walsum 2013). This research agenda should certainly include deeper examinations of how transnational family care arrangements are challenged and transformed under these regimes, and of the consequences of severely limited or curtailed rights to cross borders for 
the purposes of giving or receiving care. We have started to engage in such research, and our initial findings have led us to argue that the regimes of mobility that currently govern care-related mobility have 'immobilising' effects on people's lived experiences, including on their sense of well-being (Merla et al. 2020). The notion of immobilising regimes refers here to 'the combination of state immigration policies around migrants' entry, settlement and social, economic and political incorporation, as well as hegemonic constructions of migrants and migration. These immobilizing regimes block the physical mobility of some, while granting highly conditional mobility to others, resulting in situations of enforced and permanent temporariness and ontological insecurity' (Merla et al. 2020, pp. 15-16). Thus, these regimes affect the trajectories of transnational care circulation over time, and particularly the capacity for short-term visits, long-term re/expatriation, and circular mobility within family networks. Such restrictions can result in various combinations of immobility/mobility and entrapment. There is a crucial need to further explore these dynamics, and to bring these issues to the forefront of policy agendas.

The urgency of making transnational families' needs (and contributions) more visible to policy-makers leads us to propose a second direction for future research. To date, this literature has been largely dominated by qualitative, in-depth empirical studies that helped to illuminate the complex dynamics of transnational family life through the examination of the concrete practices and experiences of migrants and their kin. Quantitative perspectives on transnational families have mainly focused on the effects of parental migration on the health, education, and well-being outcomes of their left-behind children, usually by comparing transnational and non-migrant families (for a review, see Mazzucato 2013). These studies have recently taken an important step forward by developing cross-national comparisons (Mazzucato and Dito 2018). However, we still lack a comprehensive quantification of transnational care flows that includes all forms of care. The quantification by feminist economists of the unpaid household labour performed by women has played a key role in the 'visibilisation' and recognition of gender inequalities, and in the policy responses to them (Jany-Catrice and Méda 2011). Similarly, there is an urgent need to develop instruments and methodologies to produce large-scale data on the invisible labour performed by members of transnational families, and the contributions this labour makes to the economies of receiving and sending societies.

\section{NOTE}

1. Third Countries are countries that do not belong to the European Economic Area (European Union Member States plus Iceland, Liechtenstein, and Norway).

\section{REFERENCES}

Ahlin, T. (2018), 'Only near is dear? Doing elderly care with everyday ICTs in Indian transnational families', Medical Anthropology Quarterly, 32, 85-102. doi:10.1111/maq.12404.

Amelina, A. (2017), Transnationalizing Inequalities in Europe: Sociocultural Boundaries, Assemblages and Regimes of Intersection, New York: Routledge.

Amelina, A. and N. Bause (2020), 'Forced migrant families' assemblages of care and social protection between solidarity and inequality', Journal of Family Research. doi:10.20377/jfr-375. 
Baldassar, L. (2008), 'Missing kin and longing to be together: Emotions and the construction of co-presence in transnational relationships', Journal of Intercultural Studies, 29 (3), 247-66. doi:10 $.1080 / 07256860802169196$.

Baldassar, L. (2016a), 'Mobilities and communication technologies: Transforming care in family life', in M. Kilkey and E. Palenga-Moolenbeck (eds), Family Live in an Age of Migration and Mobility: Global Perspectives through the Life Course, London: Palgrave Macmillan.

Baldassar, L. (2016b), 'De-demonising distance in mobile family lives: Co-presence, care circulation and polymedia as vibrant matter', Global Networks, 16, 145-63. doi:10.1111/glob.12109.

Baldassar L. and L. Merla (eds) (2014), Transnational Families, Migration and the Circulation of Care: Understanding Mobility and Absence in Family Life, New York: Routledge.

Baldassar, L. and R. Wilding (2020), 'Migration, aging, and digital kinning: The role of distant care support networks in experiences of aging well', The Gerontologist, 60 (2), 313-21. doi:10.1093/ geront/gnz156.

Baldassar, L., C. Baldock, and R. Wilding (2007), Families Caring across Borders: Migration, Ageing and Transnational Caregiving, London: Palgrave McMillan.

Baldassar, L., M. Kilkey, L. Merla, and R. Wilding (2014), 'Transnational families', in J. Treas et al. (eds), The Wiley-Blackwell Companion to the Sociology of Families, Chichester: Wiley, pp. 155-75.

Baldassar, L., M. Nedelcu, L. Merla, and R. Wilding (2016), 'Migration and new media: "Being together" and "co-presence" in transnational family life', Special Issue of Journal of Global Networks, 16 (2), 131-256. doi:10.1111/glob.12108.

Baldassar, L., M. Kilkey, L. Merla, and R. Wilding (2018), 'Transnational families in the era of global mobility', in A. Triandafyllidou (ed.), Handbook of Migration and Globalisation, Cheltenham, UK and Northampton, MA, USA: Edward Elgar Publishing, pp. 431-43.

Barglowski, K., Ł. Krzyżowski, and P. Świątek (2015), 'Caregiving in Polish-German transnational social space: Circulating narratives and intersecting heterogeneities', Population, Space and Place, 21, 257-69. doi:10.1002/psp.1904.

Basch, L., N.G. Schiller, and C.S. Blanc (1994), Nations Unbound: Transnational Projects, Postcolonial Predicaments and Deterritorialized Nation-States, London: Taylor and Francis.

Bennett, J. (2010), Vibrant Matter: A Political Ecology of Things, Durham, NC: Duke University Press.

Böcker, A. and A. Hunter (2017), 'Legislating for transnational ageing: A challenge to the logics of the welfare state', European Journal of Ageing, 14 (4), 353-63. doi:10.1007/s10433-017-0431-6.

Bonizzoni, P. (2018), 'Policing the intimate borders of the nation: A review of recent trends in family-related forms of immigration control', in J. Mulholland et al. (eds), Gendering Nationalism: Intersections of Nation, Gender and Sexuality, Cham: Springer, pp. 223-39.

Brown, R.H. (2016), 'Re-examining the transnational nanny', International Feminist Journal of Politics, 18 (2), 210-29. doi:10.1080/14616742.2015.1007728.

Bryceson, D. and U. Vuorela (2002a), 'Transnational families in the twenty first century', in D. Bryceson and U. Vuorela (eds), The Transnational Family: New European Frontiers and Global Networks, New York: Berg, pp. 3-30.

Bryceson, D. and U. Vuorela (2002b), The Transnational Family: New European Frontiers and Global Networks, New York: Berg.

COFACE (2012), Transnational Families and the Impact of Economic Migration on Families. www .coface-eu.org/wp-content/uploads/2017/09/Migration-2012-COFACE-position-on-Transnational -Families-en.pdf.

Crespi, I., S. Meda, and L. Merla (2018), Making Multicultural Families in Europe, Gender and Intergenerational Relation, Cham: Palgrave Macmillan.

Degavre, F. and L. Merla (2016), 'Defamilialisation of whom? Re-thinking defamilialisation in the light of global care chains and the transnational circulation of care', in M. Kilkey and E. Palenga-Möllenbeck (eds), Family Life in an Age of Migration and Mobility: Global Perspectives through the Life Course, Basingstoke: Palgrave Macmillan, pp. 287-311.

Ehrenreich, B. and A.R. Hochschild (2003), Global Woman: Nannies, Maids and Sex Workers in the New Economy, London: Granta Publications.

Faist, T. (2017), 'Transnational social protection in Europe: A social inequality perspective', Oxford Development Studies, 45 (1), 20-32. doi:10.1080/13600818.2016.1193128.

Finch, J. and J. Mason (1993), Negotiating Family Responsibilities, London: Routledge. 
Fog Olwig, K. (2014), 'Migration and care: Intimately related aspects of Caribbean family and kinship', in L. Baldassar and L. Merla (eds), Transnational Families, Migration and the Circulation of Care: Understanding Mobility and Absence in Family Life, Abindgon: Routledge.

Fresnoza-Flot, A. (2014), 'Men's caregiving practices in Filipino transnational families', in L. Baldassar and L. Merla (eds), Transnational Families, Migration and the Circulation of Care: Understanding Mobility and Absence in Family Life, Abingdon: Routledge, pp. 170-84.

Gardner, K. and R. Grillo (2002), 'Transnational households and ritual: An overview', Global Networks, 2 (3), 179-90. doi:10.1111/1471-0374.00035.

Glick Schiller, N., L. Basch, and C. Szanton-Blanc (1992), Towards a Transnational Perspective on Migration, New York: New York Academy of Sciences.

Goggin, G (2006), Cell Phone Culture: Mobile Technology in Everyday Life, London: Routledge.

Greene, A (2019), 'Mobiles and "making do": Exploring the affective, digital practices of refugee women waiting in Greece', European Journal of Cultural Studies. doi:10.1177/1367549419869346.

Halilovich, H. (2013), Places of Pain: Forced Displacement, Popular Memory and Trans-local Identities in Bosnian War-Torn Communities, New York: Berghahn Books.

Harney, N. (2013), 'Precarity, affect and problem solving with mobile phones by asylum seekers, refugees and migrants in Naples, Italy', Journal of Refugee Studies, 26 (4), 541-57. doi:10.1093/jrs/ fet017.

Hochschild, A.R. (2000), 'Global care chains and emotional surplus value', in W. Hutton and A. Giddens (eds), On the Edge: Living with Global Capitalism, London: Jonathan Cape, pp. 130-46.

Holmes, M. (2014), Distance Relationships, Basingstoke: Palgrave Macmillan.

Hondagneu-Sotelo, P. and E. Avila (1997), “'I'm here, but I'm there”: The meanings of Latina transnational motherhood', Gender and Society, 11 (5), 548-71. doi:10.1177/089124397011005003.

Huang, S., L.L. Thang, and M. Toyota (2012), 'Special issue: Transnational mobilities of care: Rethinking the dynamics of care in Asia', Global Networks, 12 (2), 129-275. doi:10.1111/j .1471-0374.2012.00343.x.

ILO (2014), World Social Protection Report 2014/15: Building Economic Recovery, Inclusive Development and Social Justice, Geneva: ILO.

Jany-Catrice, F. and D. Méda (2011), 'Femmes et richesse: Au-delà du PIB' [Women and wealth: Beyond GDP], Travail: Genre et Sociétés, 26 (2), 147-71. doi:10.3917/tgs.026.0147.

Kilkey, M. (2014), 'Polish male migrants in London: The circulation of fatherly care', in L. Baldassar and L. Merla (eds), Transnational Families, Migration and the Circulation of Care: Understanding Mobility and Absence in Family Life, New York: Routledge, pp. 185-202.

Kilkey, M. (2017), 'Conditioning family-life at the intersection of migration and welfare: The implications for "Brexit families", Journal of Social Policy, 46 (4), 797-814. doi:10.1017/S004727941700037X.

Kilkey, M. and L. Merla (2014), 'Situating transnational families' care-giving arrangements: The role of institutional contexts', Global Networks, 14 (2), 210-29. doi:10.1111/glob.12034.

Kilkey, M. and D. Urzi (2017), 'Social reproduction in Sicily's agricultural sector: Migration status and context of reception', Journal of Ethnic and Migration Studies, 43 (15), 2573-90. doi:10.1080/ 1369183X.2017.1286971.

Kilkey M., A. Plomien, and D. Perrons (2013), 'Migrant men's fathering narratives, practices and projects in national and transnational spaces: Recent Polish male migrants to London', International Migration, 52 (1), 178-91. doi:10.1093/jrs/fet017.

Kilkey M., L. Merla, and L. Baldassar (2018), 'The social reproductive worlds of migrants', Journal of Family Studies, 24 (1), 1-4.

Kofman, E. and P. Raghuram (2015), Gendered Migrations and Global Social Reproduction, London: Palgrave Macmillan.

Kushnir, I., M. Kilkey, and F. Strumia (2020), 'EU integration in the (post)-migrant-crisis context', European Review. doi:10.1017/S1062798719000425.

Lee, S.H. (2019), "II am still close to my child”: Middle-class Korean wild geese fathers: Responsible intimate fatherhood in a transnational context', Journal of Ethnic and Migration Studies. doi:10.1080/ 1369183X.2019.1573662.

Legall, J. (2005), 'Familles transnationales: bilan des recherches et nouvelles perspectives', Les Cahiers du Gres, 5 (1), 29-42. doi:10.7202/010878ar. 
Leifsen, E. and A. Tymczuk (2012), 'Care at a distance: Ukrainian and ecuadorian transnational parenthood from spain', Journal of Ethnic and Migration Studies, 38 (2), 219-36. doi:10.1080/1369183x .2012 .646419 .

Levitt, P. and N. Glick Schiller (2007), 'Conceptualizing simultaneity: A transnational social field perspective on society', in A. Portes and J. DeWind (eds), Rethinking Migration: New Theoretical and Empirical Perspectives, New York: Berghahn Books, pp. 181-218.

Levitt, P. and B.N. Jaworsky (2007), 'Transnational migration studies: Past developments and future trends', Annual Review of Sociology, 33 (1), 129-56. doi:10.1146/annurev.soc.33.040406.131816.

Licoppe, C. (2004), “"Connected” presence: The emergence of a new repertoire for managing social relationships in a changing communication technoscape', Environment and Planning D: Society and Space, 22 (1), 135-56.

Lutz, H. and E. Palenga-Möllenbeck (2012), 'Care workers, care drain, and care chains: Reflections on care, migration, and citizenship', Social Politics: International Studies in Gender, State and Society, 19 (1), 15-37.

Madianou, M and D. Miller (2011), 'Crafting love: Letters and cassette tapes in transnational Filipino family communication', South East Asia Research, 19 (2), 249-72. doi:10.5367/sear.2011.0043.

Madianou, M. and D. Miller (2012), Migration and New Media: Transnational Families and Polymedia, Abingdon: Routledge.

Mazzucato, V. (2013), Transnational Families, Research and Scholarship: The Encyclopedia of Global Human Migration, Oxford: Blackwell.

Mazzucato, V. and D.B. Dito (2018), 'Transnational families: Cross-country comparative perspectives', Population, Space and Place, 24 (7), 1-7. doi:10.1002/psp.2165.

Merla, L. (2012), 'Salvadoran transnational families, distance and eldercare: Understanding transnational care practices in Australia and Belgium', in T. Geisen et al. (eds), Migration und Familie. Beiträge zu Bildung, Gender und Care, Wiesbaden: Springer VS, pp. 295-312.

Merla, L. (2015), 'Salvadoran migrants in Australia: An analysis of transnational families' capability to care across borders', International Migration, 53 (6), 153-65.

Merla, L. and L. Baldassar (2011), 'Transnational caregiving between Australia, Italy and El Salvador: The impact of institutions on the capability to care at a distance', in E. Addis et al. (eds), Gender and Wellbeing: The Role of Institutions, London: Ashgate, pp. 147-62.

Merla, L., M. Kilkey, R. Wilding, and L. Baldassar (2020), 'Re-thinking transnational care circulation trajectories within immobilizing regimes of migration: Implications for proximate care', Journal of Family Research. doi:10.20377/jfr-351.

Näre, L. (2013), 'Migrancy, gender and social class in domestic labour and social care in Italy: An intersectional analysis of demand', Journal of Ethnic and Migration Studies, 39 (4), 601-23. doi:10.1080/ 1369183X.2013.745238.

Näre, L. (2020), 'Family lives on hold: Bureaucratic bordering in male refugees' struggles for transnational care', Journal of Family Research. doi:10.20377/jfr-353.

Nedelcu, M. and M. Wyss (2020), 'Transnational grandparenting: An introduction', Global Networks, 20 (2), 292-307. doi:10.1111/glob.12249.

Ortiz, I., M. Cummins, and K. Karunanethy (2015), Fiscal Space for Social Protection: Options to Expand Social Investments in 187 Countries, Geneva: ILO.

Panagakos, A.N. and H. Horst (2006), 'Return to cyberia: Technology and the social worlds of transnational migrants', Global Networks, 6 (2), 109-24. doi:10.1111/j.1471-0374.2006.00136.x.

Parreñas, R.S. (2000), 'Migrant Filipina domestic workers and the international division of reproductive labor', Gender and Society, 14 (4), 560-80. doi:10.1177/089124300014004005.

Parreñas, R.S. (2005), 'Long distance intimacy: Class, gender and intergenerational relations between mothers and children in Filipino transnational families', Global Networks, 5 (4), 317-36. doi:10.1111/ j.1471-0374.2005.00122.x.

Poeze, M. and V. Mazzucato (2014), 'Ghanaian children in transnational families: Understanding the experiences of left-behind children through local parenting norms', in L. Baldassar and L. Merla (eds), Transnational Families, Migration and the Circulation of Care: Understanding Mobility and Absence in Family Life, New York: Routledge, pp. 149-69. 
Portus, L.M. (2016), 'Mobile phones: Philippines', in J.A. Murray and K.M. Madeau (eds), Pop Culture in Asia and Oceania: Entertainment and Society around the World, Santa Barbara, CA: ABC-CLIO, pp. 251-4.

Radziwinowiczówna, A., A. Rosińska, and W. Kloc-Nowak (2018), Ethnomorality of Care: Migrants and Their Aging Parents, London: Routledge.

Reynolds, T. and E. Zontini (2006), 'A comparative study of care and provision across Caribbean and Italian transnational families', Families and Social Capital ESRC Research Group Working Paper, No. 16.

Robertson, Z., R. Wilding, and S. Gifford (2016), 'Mediating the family imaginary: Young people negotiating absence in transnational refugee families', Global Networks, 16 (2), 219-36. doi:10.1111/ glob.12111.

Ryan, L. (2011), 'Transnational relations: Family migration among recent Polish migrants in London', International Migration, 49 (2), 80-103. doi:10.1111/j.1468-2435.2010.00618.x.

Schiller, N.G., L. Basch, and C.S. Blanc (1995), 'From immigrant to transmigrant: Theorizing transnational migration', Anthropological Quarterly, 68 (1), 48-63. doi:10.2307/3317464.

Shamir, R. (2005), 'Without borders? Notes on globalization as a mobility regime', Sociological Theory, 23 (2), 197-217. doi:10.1111/j.0735-2751.2005.00250.x.

Sheller, M. and J. Urry (2006), 'The new mobilities paradigm', Environment and Planning A, 38 (2), 207-26. doi:10.1068/a37268.

Urry, J. (2000), 'Mobile sociology', British Journal of Sociology, 51 (1), 185-203. doi:10.1111/j $.1468-4446.2000 .00185 . x$.

Urry, J. (2007), Mobilities, Cambridge: Polity Press.

Van Walsum, S. (2013), 'The contested meaning of care in migration law', Ragion Pratica, 2, 451-70. doi: $10.1415 / 74941$.

Vertovec, S. (2009), Transnationalism, London: Routledge.

Wilding, R. (2006), "Virtual" intimacies? Families communicating across transnational contexts', Global Networks, 6 (2), 125-42. doi:10.1111/j.1471-0374.2006.00137.x.

Wilding, R. and L. Baldassar (2009), 'Transnational family-work balance: Experiences of Australian migrants caring for ageing parents and young children across distance and borders', Journal of Family Studies, 15, 177-87. doi:10.5172/jfs.15.2.177.

Williams, F. (2018), 'Care: Intersections of scales, inequalities and crises', Current Sociology Monograph, 66 (4), 547-61. https://doi.org/10.1177/0011392118765206.

Yeates, N. and F. Owusu-Sekyere (2019), 'The financialisation of transnational care: A study of UK-based sender of remittances to Ghana and Nigeria', Journal of International and Comparative Social Policy. doi:10.1080/21699763.2019.1593879.

Yujuico, E. (2009), 'All modes lead to home: Assessing the state of the remittance art', Global Networks, 9 (1), 63-81. doi:10.1111/j.1471-0374.2009.00242.x. 